\title{
All-Turas
}

website : bit.ly/buletinalturas

\section{Youth and Social-Media: \\ The Adaptation of Dangdut Koplo Song in Islamic Da'wah}

\author{
Nuryani* \\ Universitas Islam Negeri Syarif Hidayatullah \\ Jakarta, Indonesia \\ nuryani@uinjkt.ac.id \\ Darsita Suparno \\ Universitas Islam Negeri Syarif Hidayatullah \\ Jakarta, Indonesia \\ darsitasuparno@uinjkt.ac.id \\ Syihaabul Hudaa \\ Institut Teknologi dan Bisnis Ahmad Dahlan \\ Jakarta, Indonesia \\ hudaasyihaabul@gmail.com \\ Kundharu Saddhono \\ Universitas Sebelas Maret Surakarta \\ Surakarta, Indonesia \\ kundharu@uns.ac.id
}

\begin{abstract}
The purpose of this study was to describe the role of youth in adapting dangdut koplo songs to songs that have da'wah value, and the the relationship between popular culture and religion in the adapted songs. Purposively, this qualitative study relied on some lyrics of dangdut koplo songs adapted by the into more religious ones. In analyzing the data, the researcher used the theory of cultural adaptation, social media, and Roland Barthes' semiotics. The research found out the youth adapted the lyrics from dangdut koplo into religious dangdut by changing the lyrics with the same arrangement. This was done so that people remained familiar with the dangdut music they enjoyed with a touch of religion. The devotional lyrics were characterized by advice, advocating goodness, encouraging people to stay away from evil, loving the prophet more, and social criticism. Regarding the distribution patterns of the adapted songs, there were two dominant media utilized, YouTube channels and Taklim assembly, which was usually done by santri and non-santri youth. This showed that in the process of adaptation and dissemination, the adolescents played as an adaptation agent, distribution agent, and agent of change. The study concluded the adapted religious dangdut koplo songs could be an interesting media in the millennial da'wah.
\end{abstract}

Keywords: adaptation; dangdut music; piety (preaching); religion dangdut; social media; youth

*) Corresponding Author 


\begin{abstract}
Abstrak
Tujuan penelitian ini adalah mendeskripsikan peran pemuda dalam mengadaptasi lagu dangdut koplo menjadi lagu yang memiliki nilai dakwah di media sosial. Selain itu, penelitian ini juga mendeskripsikan hubungan antara budaya populer dan budaya religi dalam lagu-lagu yang diadaptasi. Penelitian ini menggunakan teknik pengumpulan data kualitatif berupa purposive sampling. Peneliti menggunakan teori adaptasi budaya, media sosial, dan semiotika oleh Roland Barthes. Simpulan penelitian ini adalah pemuda mengadaptasi lirik dari dangdut populer ke dangdut religi dengan melakukan perubahan lirik. Bahasa merupakan media yang kuat untuk memasukkan nilai-nilai dakwah tersebut. Adaptasi lagu ini juga merupakan perekam sejarah konteks sosial budaya yang terjadi di masyarakat pada saat itu. Hubungan antara lirik sebagai data dokumen dan tanda-tanda semiotika sangat jelas. Artinya relasi yang muncul dan mengkonstruksi ide tersampaikan melalui pesan dalam lagu-lagu dakwah. Pemilihan unsur yang mudah dilihat membuat penanda dan petanda sangat relevan dengan ide dan pesan dari lirik lagu dakwah ini. Setelah melakukan kegiatan adaptasi lagu menjadi lirik yang memiliki nilai dakwah pemuda memanfaatkan media sosial untuk proses penyebarannya. Media ini sangat efektif mengingat komunitas media sosial Indonesia sangat tertarik dengan media sosial.
\end{abstract}

Kata kunci: adaptasi; dangdut religi; kesalehan (dakwah); musik dangdut; pemuda; sosial media

\title{
الملخص
}

الغرض من هذه الدراسة هو وصف دور الشباب في تكييف أغاني دانجدوت كوبلو Dangdut Koplo التي تحمل قيم الدعوة على وسائل التواصل الاجتماعي. بالإضافة إلى ذلك، تصف هذه الدراسة أيضًا العلاقة بين الثقافة الشعبية والثقافة الدينية في الأغاني المعدلة. و تستخدم هذه الدراسة تقنيات جمع البيانات النوعية في شكل أخذ عينات هادفة. و يستخدم الباحث نظرية التكيف الثقافي، و وسائل التواصل الاجتماعي، و السيميائية لرولاند بارت. أما استتاج هذا البحث فهو أن الشباب يكيفون كلمات الأغاني من دانجدوت الشعبية إلى دانجدوت الدينية عن طريق تغيير الكلمات. و اللغة وسيلة قوية لدمج قيم الدعوة هذه. يعد تكييف هذه الأغنية أيضًا بمثابة سجل تاريخي للسياق الاجتماعي والثقافي الذي حدث في المجتمع في ذلك الوقت. العلاقة بين كلمات الأغاني كبيانات وثيقة وعلامات سيميائية واضحة جدًا. وهذا يعني أن العلاقات التي تنشأ وتبني الأفكار تنتقل من خلال الرسائل في أغاني الدعوة. إن اختيار العناصر التي يسهل رؤيتها يجعل العلامات والدلالات وثيقة الصلة بأفكار و رسائل كلمات هذه الأغنية الدينية. بعد تنفيذ أنشطة تحويل الأغاني إلى كلمات ذات قيم دعوية، يستخدم الشباب وسائل التواصل الاجتماعي في عملية النشر. و هذه الوسائط فعالة للغاية بالنظر إلى أن بجتمع وسائل التواصل الاجتماعي الإندونيسي مهتم جدًا بوسائل التواصل الاجتماعي. الكلمات الأئيسة: دانجدوت الدينية؛ التكيف؛ التقوى؛ موسيقى دانجدوت شباب؛ وسائل التواصل 


\section{INTRODUCTION}

Youth always has a role in each era. During Dutch or Japanese colonial era, youth always showed an extraordinary role. It can be seen from various activities held on behalf of them. One of the most outstanding phenomena is the Youth Pledge on October 28, 1928. It became a milestone of youth's role in other activities and events. Therefore, even today, the role of youth cannot be ignored.

Nowadays, the role of youth is even more transparent in various spheres of life. As the time goes by, young people always have roles in their respective fields. One of them is the founder of phenomenal company, Gojek, who turns out to be a tough young man from Indonesia. The leader of Bukalapak, one of the largest e-commerce companies, is also a progressive Indonesian young man. Thus, it proves that youth has the role in the development of each era. The role of youth is not only seen in economic development, but also in other fields. One area that is currently in need of attention and youth is the religious field. The role in this field is clearly seen by youth.

This paper looks at the role of youth in adapting popular dangdut songs. In addition, this paper also discusses the role of youth in disseminating the results of song adaptations that have been carried out. The expected outcome is to find out the role of youth in the adaptation activities to the popular koplo dangdut song and its spread through various media, especially social media.

Kim identifies five things that become factors in adaptation; personal communication, host social communication, ethic social communication, environment, and predisposition (Kim, 2001). Utami further explains that the five factors impact what is called intercultural transformation, which is a process to achieve functional fitness, psychological health, and intercultural identity (Utami, 2015).

Personal communication occurs when someone perceives the things in their environment and then gives meaning and reaction to the objects in their environment. Host social communication and ethic social communication both comprise two kinds of communication; interpersonal communication and mass communication. Mass communication here is related to the means used in distributing and perpetuating the results of adaptation activities. If it is related at present, the media can be as social media (Facebook, Instagram, YouTube, Twitter), radio, television, and mass media (online or offline). Utami further explains that mass communication functions as a power in the adaptation process by transmitting the topics of events, social values, norms of behavior, and perspectives of traditional environmental interpretations (Utami, 2015).

To adjust, the youth can do many things. This happens in order that their existence could be accepted among the community. However, not all young people do the same thing because they have different desires and hopes. As stated by Ahmadi above that there is a role of youth who refuse to adjust in their environment. In relation to this type, Ahmadi distinguishes between the type of sloppy youth, naughty youth, and radical youth (Ahmadi, 2009).

As an effort in order to be accepted and to change the traditions in the community, the youth are still in the process of adaptation. Gerungan proposes that adaptation is a personal change to the environment (1991). Change here can be interpreted as changing oneself according to environmental conditions. Someone who selects an adaptive strategy has a high awareness of the expectations and demands of his/her environment, so that he/she is ready to change behavior (Utami, 2015a). This can mean changing the environment in accordance to the personal willingness.

Basically, there are many goals and motivations when individuals adapt, including the youth. Gudykunts and Kim (2003) state that everyone's motivation to adapt are varies. If 
they adjust themselves to be accepted by the community as individuals, then the other purpose of the adaptation is to change their environment. Youth adapt to change something they perceive wrong to what they consider right. They also think by adapting it makes their environment better. The young generation must be able to grow, help, and develop the will and ability as they can maintain and develop themselves and their environment (Ahmadi, 2009).

Songs as cultural products use language as the medium of delivery. Language is an important element to include elements of culture, social values, religious values, community background, and the current condition of society. With the language in the song, all forms of culture and conditions that are being faced by society can be recorded. Straus said if language is a product of culture (Sibarani, 2004). The language used or spoken by community groups is a reflection or a manifestation of the whole community group culture. So, we can say that the lyrics of popular dangdut songs and those that have been adapted to religious lyrics reflect the context of society itself. The problem of this study based on the background of the study above. The problems are formulated as follow namely: a) what is the role of youth in adapting dangdut koplo songs to songs that have da'wah value on social media? b) what is the relationship between popular culture and religion adapted these songs?

\section{METHOD}

This study aims to describe the role of youth in their efforts to preach through adapting viral dangdut songs. Therefore, the method used in this research is descriptive qualitative method. This method is used to describe a research data more objectively and as it is. By using this method, it allows researchers to explain the role of youths seen in da'wah activities through adaptation of viral dangdut songs. In addition, using this method also allows the researcher to describe distributing the adapted songs.

The data in this study were dangdut songs in the Koplo genre that were viral. In addition, the data is also as songs adapted from the dangdut koplo song and the distribution process. With this form of data, the data used collection technique purposive sampling. By using this data collection technique, it is possible for researchers to retrieve data under the research objectives. To see the songs that were viral, the researchers used YouTube. In addition, the researcher also using other social media to choose data, like Facebook or Instagram. Active user social media from both of the social media doing a campaign to listening to the songs both with religious lyrics or general dangdut. Based on these techniques, the data used in this study were the song "Sayang" which was sung by Via Vallen, "Ditinggal Rabi" by Nella Kharisma, and "Jaran Goyang" also by Nella Kharisma. The three songs were used as data because they were very popular among the public and also had very many visitors and viewers on the YouTube channel. Based on the data viewer, the researcher interpreted it. Meanwhile, to get data on the distribution of adapted songs, researchers used the YouTube channel and also other social media such as Facebook.

This research focuses on the use of the language found in changes in song lyrics performed. In the changes made, the contextuality can also be seen. Therefore, the use of interpretation techniques is the best choice (Purbani, 2010). Meanwhile, the data collection technique was carried out by taking viral dangdut koplo songs and songs whose lyrics adapted from the viral songs. This type of research is phenomenological research. Therefore, researchers use the phenomenology paradigm as a perspective in constructing research results based on the interpretation of the song lyrics adaptation of dangdut koplo. Phenomenology (Sobur, 2013) etymologically is the science of phenomena. Meanwhile, phenomenology refers to a speculative theory of dichotomy, a visible and invisible difference (Setiaji, 2017). 


\section{FINDINGS AND DISCUSSION}

Tri says that human adaptation is needed to get idealized condition in relation to other parties and environmental changes. Adaptation is not only occurred in personal matters but can be in various things outside of themselves. For instance, is the adaptation to certain activities, things, or genres that are changed by them (Susilowati, Erma, Wasino, 2016). Along with the increased development of social media, it is found the result of young generation's creativity as a form of their adaptation efforts in addressing many things. We find various types of songs adapted by youth on YouTube. From one type of song adapted to another type. In addition, adaptation forms are also found from one lyric to another. However, it needs to be understood that in the process of adaptation, some have changed and some have not changed (Utami, 2015a).

The youth's passion for music also receives special attention. Music is a cultural activity that is very familiar with human life (Mualim and Erowati, 2015). Youth are very familiar with this cultural activity and the music world. In various music concerts held by youth, they massively fill out the location. Every young man has a passion for different music. Youth has always been a "wetland" for the music industry both in Indonesia and abroad. Therefore, it is not surprising that almost every type of music is presented and promoted by using youth as icons. This includes dangdut music. Dangdut in fact experienced a development, one of which is dangdut koplo (Setiaji, 2017).

In Indonesia itself there are various types of music that are quite popular in various circles including the younger generation. They are pop music, rock, nasyid, religious song, dangdut, keroncong, campur sari, and hip hop. Dangdut music is still divided into several genres, including classical dangdut and koplo dangdut. The most interesting dangdut music genre today which is highly developed and has people-enthusiasts is the koplo genre. This is proven by the fact that when the koplo dangdut music video is uploaded on YouTube channel, it will be immediately seen by many viewers. For instance, the song "Darling" sung by Via Vallen which was uploaded and instantly watched by 184 million times in only a relatively short time.

Koplo dangdut music has its origin from the Surabaya localization in the mid-1990s. East Java became the basis for the emergence of Koplo dangdut. The presence of this genre of music adds to the repertoire of dangdut music that has been developing. At the beginning of its emergence, this type of music was only known regionally. However, along with its development this type of music is now popular on a national scale (Setiaji, 2017). The name koplo is taken from one type of drug name "Koplo pill" (Damaledo, 2018). This type of pill (medicine) is actually a type of illegal drug that should not be consumed in general. That is because the effects are less good for those who consume. However, the users in localization says its opposite. Using this drug can actually make users more excited. Therefore, it is not surprising that every time they enjoy the koplo genre songs, the viewers are always "prancing" with excitement.

The spirit can be seen from the audience's reaction when listening to koplo dangdut music. However, the lyrics created and the music arrangement will still attract viewers and listeners to dance and "prance", as one of Via Vallen's very popular song entitled "Bojo Galak" (fierce spouse), whose lyrics is "if you are strong, then do it, if not, just go for coffee". The lyrics seem to describe no matter what the conditions are, everything must be responded with positivity, relax, and happiness.

Song lyrics for the type of koplo dangdut music have very diverse themes/topics, heartache, breakup, household and even disloyalty theme from the lyrics for example. With such lyrical themes, the fans and connoisseurs of this music type seem not to care too much. However, some also really enjoy and understand the contents of the song lyrics. The thing 
that makes them really interest is the type of music that can be enjoyed with enthusiasm. Therefore, whatever the contents of the song lyrics are, the crucial point is how to enjoy the music with dancing.

Based on the phenomenon of huge fan as described above, it turns out to attract many parties to adapt the lyrics. There are several parties adapting the lyrics that were considered too vulgar to the more acceptable lyrics. The adaptation of song lyrics in popular terms is known as "covering" the song. However, there is a significant difference between covering songs and adapting lyrics. Therefore, this paper uses the term adaptation of piety song lyrics instead of using the term "covering". The activity of adapting song lyrics performed by the community primarily by young people is changing the song lyrics which by the general public are deemed unfeasible to be heard by all groups. They change the lyrics of the song with lyrics that contain advice and lyrics of salawat.

Ghazalba explains salawat or singiran in its development has led to many variations in form and function (Ghazalba, 2020). Salawat which was originally a prayer of mercy and greetings for the Prophet, has now developed into poems related to the meaning persuasive, identity, reward, and punishment in the teachings of Islam. As a result, the content of salawat is no longer only praising the prophet. There are also suggestions for inviting goodness and threats or punishment if they do not follow the teachings. Likewise with this article that young people adapt or change song lyrics to be more "Islamic" in which contains advice to always follow the teachings of the Islamic religion. However, changes in the lyrics also still have elements of praise to the Prophet Muhammad saw.

Related to the factors described above as the discussion of this paper, it is divided into two (2) sections of the discussion. This is undertaken in order to explain answering the questions. The two sections will be discussed include (1) patterns of adaptation and patterns of dissemination, and (2) the role of youth in the process of adaptation and dissemination. The two sections will be discussed using an introductory scheme, data presentation (can be as tables, diagrams, or pictures), and data analysis. Data as songs (song lyrics) are taken from the internet (YouTube channel) and then interpreted at the analysis.

\section{The Patterns of Adaptation and Dissemination}

There are several dangdut songs with the koplo genre that are very favored presently. One of this community is the youth. It can be shown from the "booming" audience in teenager category who flock to the koplo dangdut music concert even though there are many other viewers from various generations. The activity of adapting song lyrics is actually not only done this once but has been done by several other parties, such as research conducted by (Waluyajati and Syahuri, 2019). The study is a reflection of research that has been conducted on the KHA Maulana Jamaludin Al-Busyiri (Hajj Ule) and KH Salimul Apip (Ajengan Apip). Both are actively promoting salawat activities from stage to stage with musical accompaniment in remote corners of West Java. On the stage, the salawat poetry is sung by borrowing notes from popular songs on the public's tongue, such as the tune of "iwak peyek", "tum hi no", and so on. In contrast to the study, the subjects of the study were seniors, so in this study the subjects of this study were young men who composed popular song lyrics with lyrics that contained advice.

Dangdut music concert with koplo genre is very popular from various background. The phenomenon as shown in the picture occurs not only once, twice, or three times of a concert but almost in every concert the same phenomenon will be found. In Indonesia (especially Java) there are several dangdut music concert organizers, including the Malay Orchestra (abbreviated as OM) Monata, Pallapa, New Pallapa, and Sera. Based on the tirto.id's results of research (2018) OM Monata is considered as the Malay orchestra that firstly introduced 
the koplo genre of dangdut music. OM Monata popularized koplo dangdut through the touch of a guitarist who is also the OM "frontman", Cak Sodiq. By the development of OM Monata, many other Malay orchestras have sprung up with many local singers.

The popularity of koplo dangdut music among society is used by the parties to adapt in order to be more meaningful. Some parties adapt the music by changing the song lyrics that have more positive values. A Song lyric of koplo dangdut preserved vulgar is converted into lyrics that contain the value of preaching. They aim of the songs adapted is to reflect the values of piety that can be taken as lessons of life. As the research conducted by Susanto related to song lyrics and piety representation (Susanto, 2018). Susanto concludes that song lyrics can be used as a medium to ignite enthusiasm and tie solidarity among supporters (which in this case is a demonstration of Islamic action). Susanto further explains, the songs use language which represents the piety of the supporters of the action while it shows a political identity that distinguishes us and them. Language is part of a social phenomenon whose emergence can be influenced by various factors, both internal factors of language and factors outside of language (Jazeri, 2017). As a songwriter who can be influenced by various factors in his creation, he chooses diction according to what is felt and what is expected. Likewise in the song adaptation activity, these young people hoped that the lyrics they adapted could describe the situation they hoped for.

The adaptation of song lyrics from dangdut koplo to the propaganda of song lyrics is religious coding-decoding-recoding. Crawley in Waluyajati says "True religion cannot live, and cannot be understood for what it is, unless its form is continually changing (Waluyajati, 2019). On this change its essence depends. Waluyajati also revealed that Indonesian scientists who also expressed the same thing were Kuntowijoyo. According to him religion must continue to do coding-decoding-recoding. The essence of religion must be presented in cultural codes that are under the current and the spirit of the times. Religion which does not make the necessary changes will soon become obsolete and abandoned by its adherents. This is clearly seen in the development of Islam today. With the role of young people trying to adapt the song lyrics, the religion of Islam is no longer considered old-fashioned. The public can still sing to the accompaniment of Koplo music but with lyrics that are more worthy of hearing by all circles.

Adaptation of piety by these parties certainly has a purpose and motivation. As illustrated in the lyrics of the songs created can be seen at least one of the several goals they made the adaptation, it is preaching. Adaptation to the piety is only conducted on the song lyrics that are changed while the type of music remains. This was undertaken so that these lyrics can also be received and listened by koplo dangdut music fans. The acceptance is expected to be the same as the acceptance of koplo songs with original lyrics. Afterwards, it is hoped that the connoisseurs can absorb the values of preaching and piety reflected in the lyrics.

Based on the data it can be explained in the following discussion. The song "Sayang/Darling" was popularized by a singer who initially joined a local Malay orchestra in East Java. That song makes the singer gain an extraordinary popularity. The singer is Via Vallen or whose real name is Maulidia Octavia. With her popularity, Via finally got the chance to sing the official song at the Asian Games in Jakarta, 2018.

The popularity of that song is indeed not in doubt. Based on the release submitted by tirto.id, since it was first uploaded on 24 February 2017 via the ascadamusik YouTube channel, this song was immediately popular (Damaledo, 2018). This is indicated by many parties who copied the song's video on YouTube channel. Over 180 million viewers have seen the video of the song in a relatively short time. The lyrics are easy to remember and the 
type of music while still in trending makes this song can be enjoyed by people from various background.

The momentum of the song's popularity "Sayang/Darling" inspired others to adapt by changing the lyrics of the song. Song lyrics that are considered too "mundane" are converted into song lyrics that contain the value of piety or preaching. The following excerpts from the original song lyrics "Sayang/Darling" and adapted song lyrics entitled "Aurat/Private Parts" which was popularized by Gus Aldi.

Based on the adapted lyrics, it can be explained that the motivation for adapting the song is to explain the irony that is happening right now. The woman as the subject of the song's adaptation is described as a perfect woman. However, perfection is very ironic because it is "exposed" and they are not very much concerned with their private part because they do not cover it.

Another irony is also illustrated through the following lyrics. The adapters convey that this time we are in a darkness era. Many beautiful women take care of their body just to show it for pride. The women are considered not to love her father and do not maintain their private parts for their muhrim (husband). They make up, dress tight, and do body treatments but to be "enjoyed" by public. This makes the song adapters also give advice so that they immediately make repentance before it's too late when death is approaching. Adapters expect before it's too late, before covered with the shroud, the women are asked to immediately cover their private parts.

The song "Aurat/Private Parts" was popularized by Gus Aldi. From some of his uploads on social media, he is interested in preaching through writing on social media. Some writings written on facebook accounts contain life's advice. One of the "statuses" he wrote was also related to advice to women for not exposing their private parts. Here is one writing traced from Gus Aldi's Facebook page.

"Use Internet for a good purpose not only to trick girls into what accounts people put in and don't show the nakedness that God forbids, remember it can damage the good deeds" (Rahman)

The adaptation of the piety of the song "Aurat/Private Parts" was uploaded also on the YouTube channel by the person concerned. Since it was uploaded on October 25, 2017 this song has been viewed by over 1 million viewers. With the large number of viewers, it shows that there are actually many people who are happy with the results. The hope is not just to be a viewer but also to change as what is expected by the adapters of the song. Saefudin said that in the discourse of the Kutbah or lecture, there are many utterances to express certain intentions using language with a variety of sentence structures (Saefudin, 2017). That is the essence of doing da'wah activities that can be done in various ways. One way that this can be done is by using songs as the ingredients. This was done in order to refine the language so that it did not give the impression of patronizing or giving doctrine. Through da'wah songs it can be accepted by various groups.

The original "Sayang/Darling" song sung by Via Vallen is very popular indeed. This is evidenced by many viewers who watch the video song on the YouTube channel. Therefore, it is not surprising that there are several parties who use it as a preaching media. Besides being adapted by Gus Aldi with the title "Aurat/Private Parts", the song "Sayang/Darling" was also adapted by The Abdi Dalem's lyrics through DJDJ Production with the title "Sembahyang/Praying" in Indonesia it means Salat.

The Abdi Dalem is a group of young people with a distinctive Javanese style who change the lyrics of the song Via Vallen using the Javanese language. Since it was first uploaded on the YouTube channel, this song has reached its own place for dangdut music lovers with preaching lyrics. This is evidenced by the large number of viewers, which exceed 
over 700 thousand viewers. Although it could not gain 1 million viewers, but the number of viewers is significant in a short time proving that there are still many parties who enjoy the type of lyrics written. Besides being able to be seen on the YouTube channel, this video is also viral in the WhatsApp application. Therefore, this group made the song "Sayang/Praying" for the second volume.

This group deliberately uses Javanese as the language of instruction to reinforce their identity. They want to emphasize that they are Javanese people so that the clothes used in the video also use Javanese traditional clothes namely lurik and blangkon. They also use the name of group that characterizes Java, The Abdi Dalem. The Abdi Dalem has three (3) members with one vocalist, one drummer, and one violinist.

Similar to the activities of piety adaptation of song lyrics performed by other parties, the song "Sayang/Praying" is also adapted for a specific purpose. The lyrics presented contain a lot of advice. The following are excerpts of the song's lyric "Praying" with a free translation into Indonesian by the author.

"Sembahyang"
Sembahyang ono limang wektu
Ngge sangu matimu
Mengharap rak bakal lali
Sembahyang nganti memutih rambutmu
Ngge bekal nang akhiratmu

"Sembahyang"

Sembahyang ono limang wektu

Ngge sangu matimu

Mengharap rak bakal lali

Ngge bekal nang akhiratmu

In the lyrics presented, the contents are advice and encouragement to pray five times a day. The reward of the activity is what every human will bring when approaching death. Therefore, it is expected that they still do praying until their hair turn grey. They will lose if they do not pray. When they have died, there is nothing else to talk to. In a consequence, they will suffer if they leave praying while living in the world. The lyrics in the adaptation of the piety of the song "Praying" also invite humans to remember live after death. Therefore, do not let the prayer left whatever happens. The lyrics is emphasized containing preaching or advice that can be contemplated and practiced by music lovers.

Other song lyrics that also attract other parties to adapt are a song called "Jaran Goyang" which was popularized by Nella Kharisma. Nella Kharisma is actually a famous local singer through several local OM in East Java. She is existed and joined as a singer in several OM such as Sera, Monata, and Pallapa. However, the presence of social media makes her name famed. The enthusiast types of music dangdut koplo through social media helps her name raised through some very viral songs. Some are popularized by Nella Kharisma including "Bojo Galak", "Ditinggal Rabbi", "Mundur Alon-Alon", and so on and so forth.

Along with the popularity of these songs, there are several songs which then attract the interest of other parties to adapt the piety of the lyrics. One of them is the song "Jaran Goyang" which is very popular with a viewer of over 227 million in only a temporary period of time. With this popularity, not long after this song is on the YouTube channel, the song "Jaran Goyang Salawat version" is found with the title "Lovers/followers of the Prophet". Video song "Lovers of the Prophet" is uploaded on the YouTube channel and it immediately got a suitable response from connoisseurs and dangdut lover. This can be seen from the number of viewers who viewed over 9.7 million in a short time.

The song "Jaran Goyang Salawat version" was popularized by the Shalawat Syubbanul Muslimin Group. Salawat group is supported by two vocalists, Gus Azmi and Gus Hafid. Both of them are santri in Islamic Boarding School Nurul Qodim Kalikajar, Paiton, Probolinggo. Gus Azmi whose full name is Muhammad Ulul Azmi Askandar al-Abshor is the main vocalist in the salawat group. Now Gus Azmi has emerged as a new idol for 
millennial who is always involved in recitation. Another vocalist is Gus Hafid whose full name is Hafidzul Ahkam. Because both of them emerged as new idols, then this salawat group adapts another popular song entitled "Ditinggal Rabbi" with the adaptation title of "Santri bukan Artis/Santri are Not Entertainer". With the adaptation of this song, they emphasize they are santri and implore them not to be idolized.

The characteristic possessed by the salawat group are the lyrics presented in the adaptation process carried out. Because this is a salawat group, most of the lyrics presented contain encouragement to always sending blessing and peace to the Prophet. In addition, the lyrics also contain an encouragement to always love the Prophet as a perfect human being and who deserves to be idolized. The following are excerpts from the two adapted song lyrics, "Santri bukan Artis/Santri are not Entertainer" and "Salawat version of Jaran Goyang (Lovers of the Prophet)".

"Jaran Goang versi Salawat"
Jangan bilang kau pemuda kuat
Jangan mentang-mentang bad
Bila sering kau tinggalkan sal
Innalillah innalillah

"Santri bukan Artis"
Syuban lovers nusantara
Akhi Ukhti, sahabatku semua
Semoga takkan menyerah
Cintai Rosulullah
Lelahmu menjadi Lillah
Jadilah penggemar majlis
Mencintai Nabi begitu manis
Bukan lebay menangis
Idolakan vokalis
Kami santri bukan artis

"Jaran Goang versi Salawat" Jangan bilang kau pemuda kuat Jangan mentang-mentang badan sehat Bila sering kau tinggalkan salat

\author{
"Lovers of the Prophet" \\ Don't say you're a strong young man \\ Do not just because a healthy body \\ When you often leave the prayer \\ Innalillah innalillah
}

"Santri is not an Entertainer"
The noble Solawat lovers
Akhi Ukhti, my best friends
Hopefully you won't give up
Love the Prophet
Your fatigue being lillah
Become a fan of the assembly
Loving the Prophet with pleasure
Not crying excessively
Make the vocalist as your idol
We are santri, not entertainer

Based on the adaptation of quoted lyrics above, there are many values of piety or preaching delivered. Adapters want to invite music connoisseurs to always be at peace. It is important so that humans will get syafaat or intercession from the Prophet Muhammad in the hereafter. This group also convey that loving the Prophet was a pleasure. For anyone who does not stop doing salawat and are tired of doing it, they will be rewarded by Allah. In the song's adaptation's lyrics, the target is also clear, it is the youth. It can also be seen in the lyrics an encouragement to stay away from arrogance, young people should not only think about mundane things, young people are encouraged to realize the importance of salawat, and continue to perform prayers.

Apart from using the theory of cultural adaptation, this research also uses the semiotic theory of Roland Barthes with a constructivist approach. Roland Barthes was chosen because he emphasized the interaction between texts with personal and cultural experiences, the interaction between texts, and the cultural conventions of a society

Based on this concept Barthes Semiotic Study against Islamic koplo song in everyday life is used. Muslim song in Indonesia has been considered normal, natural, widely listened to. Muslim koplo song is listened to by Muslim people because there are Islamic teachings and entertainment. Because of its acceptable existence, muslim koplo songs have become a sign that has to do with the underlying background. From denotative reviews, are muslim song is a form of communication that conveys a distinctive feature of the culture it carries. 
This culture is the order and rules of behavior for muslims contained in the Qur'an and the Sunnah.

In the study of Barthes semiotics, in principle, lyrics muslim koplo song is a marker (language), while the symbol (concept) is "language and culture are used by Muslim composer". The relationship (sign) between markers (language) and symbols, in this case, is a religious relationship, which Barthes calls ideology. In its development, the use of Muslim Koplo songs appeared in various forms, to be consumed and associated with the hearer's culture, with identity, as well as the brand.

The workings of Roland Barthes' semiotics (Cobley, 2006, pp. 690-693) to analyze meaning can be drawn as followsm signifier, signified, denotative sign, connotative signifier, connotative signified, connotative sign related to language and culture. The form of language units with cultural terms in the song lyrics is found in the lingual unit which means culture as words. The cultural meaning words in the song lyrics are as greeting words. The following is an example of a culturally meaningful lingual unit as a greeting word. In the Dictionary (Cobley, 2006, pp. 690-693) Al ma'any https://www.almaany.com/id/dict/ar-id the word أخجِ / akhi / means 'brother' and / أخْتِي / means 'sister'. In the first array, there are greeting words or calls. This word is used to distinguish the call of a man and another that of a woman. The use of these words in the lyrics of this song is identified as a symbolic form (symbolic form) for the greeting system in a limited community. Historically, this greeting appears in: a) study forums, b) daily conversations in the internal members of the Salafi movement involving friends of the study community, c) Ustaz, d) writings from print and online media, e ) Islamic songs. Judging from the objectification process, the words "akhi" and "ukhti" emerged because there was a collective agreement. The agreement on the use of words, meanings, and contexts of using the words akhi and ukhti develop into an identity. In addition, this form appears as a form of control between members so that they always remember and practice Islam as the culture of the salaf ash-shalih. This data shows the relationship between language and culture according to Roland Barthes. In short, the continuous use of the word in everyday life from generation to generation is a form of structured structure. The impact symbolically forms a distinctive meaning, namely those who differ in religious and ideological practices and views. The words "akhi" and "ukhti" are now included in the realm of da'wah objects through songs.

In the data, the word tired becomes / lillah / لِّ In everyday life, Indonesian people often meet or pronounce Arabic. This is because as Muslims, their lives cannot be separated from Arabic terms as our way of life is the Al Quran in Arabic. Lillah is short for lillahi ta'ala which comes from Arabic with Arabic script: لََِّّتَعَاًَى This phrase-shaped language unit means 'for Allah ta'ala.' This language unit is pronounced when there is a discussion related to intention. The cultural meaning that can be obtained from this language unit is that a Muslim in his work, activities, and fatigue must intend for Allah. This is done because every deed that someone does in this world only for Allah. The lyrics of the song that have been adapted are a reminder for those who hear or read the lyrics of this song to understand the importance of learning Islamic religious knowledge, understanding each other, and understanding each other. Everyone will carry out a job or activity must be preceded by intention. The function of this song contains the message the songwriter wants to convey that every Islamic song reflects a cultural system that regulates the relationship between humans and God and their environment.

The songs analyzed in this article are songs that have Islamic cultural meanings implied in the lyrics. This underlies the selection of this song as an object of research. The following is an example of Roland Barthes' semiotic analysis of the data. 
a) In the case of the markers in the song "Ditpun Rabi" and "Surat Cinta untuk Nabi". Every word in the song lyrics can be seen and read by the sense of sight, and can be heard by the sense of hearing, is an identifiable aspect of the marker. The marker aspect of this song constructs an explanation of the characters who are pious and salihah. The situation that is built into the song as it uses the greeting words "ukhti" and "akhi" is a marker of Islamic community; "Rosulullah" is marker the referential meaning by its usage when referring to people. It refers to messenger of God, Muhammad. The word "lillah" is a marker literally means 'for Allah'. It contains any form of donation given in the cause of Allah on a purely voluntary-bases. This donation giving different with "zakah" that one is empowered to give rather it is given for the betterment of others, be it Muslims or people of other faiths. The word "Nabi" is a word used by Jews \& Muslims to refer to a Prophet, who may have just followed a previous Prophet having received God's message or the "Nabi" himself may have received the message. The word "santri" refers to people in Javanese who practice a more orthodox version of Islam. Members of the santri class are more likely are oriented to the mosque, the Qur'an, and perhaps to Islamic canon law (Sharia).

b) In the case of a sign, the concepts that can be associated with the words of the marker are the description of friends, love of the Prophet, students, people who always study in an assembly, always give alms to the rosul, hope, about love, desire, loyalty, strength, and sincerity of love for the rosul. The results of the analysis of language units as words or phrases with denotative meanings, connotative meanings, and cultural links in the data. At the denotation level, the main character tells the story as someone who loves Allah and the Prophet. The main character of love for Allah, the Messenger of fellow humans, and the natural environment. It is based on knowledge and compassion. In another stanza of data that the main character wants everyone to enter heaven. In addition, the main character is advised to obey the teachings of the prophets.

This expresses the love, hope, and admiration the main character feels. At the connotative level, the lyrics describe the things that underlie the love relationship to Allah and the Prophet, namely praying, praising, glorifying God, caring or caring for others, patience, and loyalty. It is believed by the songwriter that every person in their daily lives must do worship and do good deeds. Actions are not just words, but there must be actions that prove the sincerity of love for God, apostles, and fellow human beings who love one

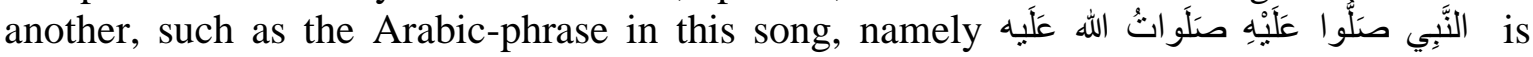
pronounced /annabi shollu alaih, sholawatullahi'alaih/. The meaning of this phrase is 'He is the Prophet, so pray to him. May Allah bestow all good upon him.'

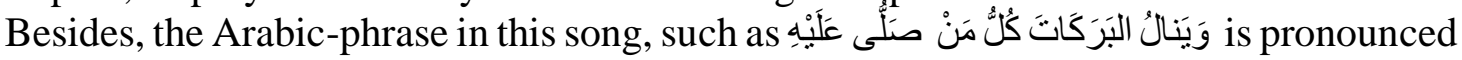
/wayanalul barokat kulluman sholla'alaihi/. The meaning of this phrase is 'Everyone who prays to him will get a blessing.' The Indonesian phrase in this song such as "jangan salah niat" refers to "every activity begins with an intention. This intention needs to be accompanied by worshiping Allah sincerely without expecting anything in return from humans.' In brief, this phrase is identified as a denotation. The denotation of a word based on Roland Barthes semiotics refers to, its literal definition - its dictionary definition - and contains no emotion.

The Indonesian phrase "membumikan sholawat" in this song refers to "Sholawat is a prayer for the Prophet Muhammad SAW. It is the same as the sentence of remembrance to remember Allah SWT.' People who often read Sholawat will benefit from reading, blessings, and goodness for themselves. Besides, Muslims are encouraged to read Sholawat Prophet Muhammad SAW. It proves of our beloved in Him. It also a means to achieve happiness in this world and the hereafter. The word "membumikan" comprise two element bumi + mem-kan. The word "sholawat" is a noun. Based on this word-formation bumi, 
sholawat are identified as signifier. However, in the phrase's form "membumikan sholawat," this language form is identified as a connotative signifier. The reason of identifying as connotative signifier or secondary because it has a cultural meaning of signs; or "signifying signs," signs that are used as signifiers for a secondary meaning, e.g., the phrase "membumikan sholawat" signifies that the narrator in this song invites, introduces personally, imitates the personal of Rasulullah SAW, both in his speech, actions, and attitudes as Uswatun Hashanah.

Based on these things, it can be said that the song lyrics in the data are very rich in meaning both in denotation, connotation, and cultural meaning. The meanings depicted in the song lyrics open the concept of a connection between cultures that are considered popular which can then be adapted into the religious culture. The process of adaptation and dissemination through social media which is carried out massively makes these two cultures closely attached and very attractive to the Indonesian people, especially social media lovers.

Young people here play a big role in the process or adaptation of the piety of koplo dangdut song lyrics. In addition, youth also have a huge role in the process of dissemination through various media. Youth can be said to be agents of adapters. This can be seen from the parties who adapt and popularize the song. Youth can also be said to be agents of distribution. They do this by uploading on social media, watching and then sharing it through various media. Based on this role, it can also be said that youth are agents of change. Youth bring changes, offering and choosing the type of song that can be enjoyed by music lovers particularly koplo dangdut. If koplo dangdut music lovers feel uncomfortable with the lyrics while they want to enjoy the music, then there is an option to continue enjoying the music with lyrics that contain piety values.

\section{CONCLUSION}

This part contains the conclusion and suggestion from the writers after studying the analysis on Roland Barthes' semiotic analysis of dangdut koplo songs. There are two problems of this study. First, is what the role of youth in adapting dangdut koplo songs to songs that have da'wah value on social media. It describes youth and social media have a big role in adapting song lyrics and their distribution. The youth adapted the lyrics from popular dangdut to religious dangdut by changing the lyrics. Language is a powerful medium to include these da'wah values. The adaptation of this song is also a historical recorder of the social and cultural context that took place in society. Semiotic it can be conveyed that the language used in the song lyrics, both those that have not been adapted and those that have been adapted, become separate markers and markers in the social interactions and cultural adaptations that occur. Through this language, the existence of song lyrics becomes more interpretable both in a social and cultural context. Based on the semiotic view there is a close relationship that Indonesian people like culture, both popular and religious. Secondly, all the signified from denotation as the first order of signification becomes the signifier for the connotation as the second order of signification. The writers analyzed it by using Roland Barthes theories, also analyzed based on the message of the song's plot. The relationship between the lyric as document data and the semiotics signs is close. It means that relation of emerge and constructed the ideas and messages of da'wah songs. The choose of easily seen elements which conduct signifier and signified have to be relevant with the idea and message of this da'wah lyrics song.

It suggests that the next researchers who are interested in choosing semiotics as their stand point take the data from other sources like Islamic da'wah in Javanese or Sundanese folk songs or every song that conducted in an album. The next researcher can analyze other component of semiotics sign such as Peirce Sanders or Saussurean model, myth, 
Nuryani, Darsita Suparno, Syihaabul Hudaa, Kundharu Saddhono

Youth and Social-Media: The Adaptation of Dangdut Koplo Song in Islamic Da'wah

paradigmatic syntagmatic system, code, triadic diagram. By using different sources of data, they can get new variety of semiotics study.

\section{ACKNOWLEDGMENT}

We would like to express our gratitude to the Ministry of Religion and all the organizing committees of AICIS 2019. We were given the opportunity to present this article at this activity so that it received valuable input. Based on this input we made a revision which was finally completed and we would like to convey this article widely through publication in scientific journals. Hopefully there will be more opportunities for us to be involved in similar activities so that we can produce more varied and useful works.

\section{REFERENCES}

Ahmadi, A. (2009). Ilmu Sosial Dasar. Rineka Cipta.

Bintari, P. N. dan C. D. (2016). Peran Pemuda sebagai Penerus Sambatan dalam Rangka Pembentukan Karakter Gotong Royong. JPIS: Jurnal Pendidikan Ilmu Sosial, 25(1).

Cristover, D. (2019). Peran Pemuda Lintas Agama dalam Meningkatkan Kerukunan Umat Beragama di Provinsi Kalimantan Timur. Jurnal Paradigma, 8(2).

Cobley, P. (2006). Barthes, Roland: Theory of the Sign. Science Direct: Elsevier. https://doi.org/10.1016/B0-08-044854-2/01395-X

Damaledo, Y. D. (2018). Kisaran Pendapatan Via \& Nella dari Video "Sayang” \& "Jaran Goyang." Tirto.Id. https://tirto.id/kisaran-pendapatan-via-nella-dari-video-sayangjaran-goyang-cAPx

Fahrudin Mualim, R. E. (2015). Perbandingan Gaya bahasa Pada Puisi "Ibu" Karya Mustofa Bisri dengan Lirik Lagu "Keramat" Karya Rhoma Irama. DIALEKTIKA: Jurnal Bahasa, Sastra Dan Pendidikan Bahasa Dan Sastra Indonesia.

Gerungan, W. . (1991). Psikologi Sosial. PT. Eresco.

Ghazalba, M. A. (2020). Ideologi dan Hegemoni dalam Shalawatan (Study of The Ideology of Althausser and Gramsci's Hegemony). Jurnal Nusa, 15(1).

Gudykunts, W. and Y. Y. K. (2003). Communicating with Stranger (4 Edition). Mc-Graw Hill Companies, Inc.

Istriyani, R. dan Y. (2016). Media: Causes and Strategies to Overcome Islamophobia (Psycological and Sociological Study). Qudus International Journal of Islamic Studies (QIJIS), 4(1).

Jazeri, Mohamad. (2017). Sosiolinguistik: Ontologi, Epistimologi, dan Aksiologi. Tulungagung: Akademia Pustaka

Kim, Y. Y. (2001). Becoming Intercultural: An Integrative Communication Theory and Cross-Cultural Adaptation. Sage Publication.

Konser New Palapa. (n.d.). https://www.google.co.id/search?q=konser+new+pallapa\&safe $=$ strict $\&$ source $=1$ mms \& tbm $=$ isch $\&$ sa $=X \& v e d=0 a h U K E w i E 39$ rr2afkAhWsIbcAHclVC bcQ_AUIESgB\&biw=1252\&bih=600\#imgrc=hwmbVfhaD4nqjM:

Purbani, W. (2010). Metode Penelitian Sastra. Jurnal Universitas Negeri Yogyakarta. Http://Staff...http://staffnew.uny.ac.id/upload/131874171/pengabdian/metodepenelitian-susastra.pdf

Rahman, A. (n.d.). No Title. Facebook. https://web.facebook.com/aditiya.rahman.16121/ 
timeline? 1 st=1749234401\%3A100035601780939\%3A1567108025)

Saefudin. (2017). Realisasi Strategi Kesantunan dalam wacana Dakwan (Satu Kajian Pragmatik pada Teks Ceramah Agama dan Khutbah Jum'at). Buletin Al-Turas, XXIII(1).

Setiaji, D. (2017). Tinjauan Karakteristik Dangdut Koplo sebagai Perkembangan Genre Musik Dangdut. Jurnal Handep, 1(1).

Sibarani, Robert. (2004). Antropolinguistik: Antropologi Linguistik dan Linguistik Antropologi. Medan: Penerbit Poda

Sobur, A. (n.d.). Analisis Teks Media. PT Remaja Rosdakarya.

Susanto, D. (2018). Lirik Lagu dan Representasi Kesalehan dalam Aksi Bela Islam. Kandai, 14(1).

Susilowati, Erma, Wasino, dan C. B. U. (2016). Pola Adaptasi dalam Interaksi Sosial Masyarakat Hindu di Dukuh Jomblang, Desa Dukuhringin, Kecamatan Slawi, Kabupaten Tegal. Journal of Education Social Studies (JESS), 5(2). http://journal.unnes.ac.id/sju/index.php/jess

Utami, L. S. S. (2015). Teori-Teori Adaptasi Antar Budaya. Jurnal Komunikasi, 7(2).

Waluyajati, R. S. R. dan A. S. (2019). Budaya Pop dalam Tradisi Shalawatan pada Masyarakat Pedesaan. Religious: Jurnal Studi Agama-Agama Dan Lintas Budaya, 3(2). Journal.uinsgd.ac.id/index.php/Religious 
Nuryani, Darsita Suparno, Syihaabul Hudaa, Kundharu Saddhono

Youth and Social-Media: The Adaptation of Dangdut Koplo Song in Islamic Da'wah 